\title{
Noni dan Temo dalam Serial Drama Jepang: Kajian Sintaksis dan Semantis
}

\author{
ARSYL ELENSYAH RHEMA MACHAWAN \\ U niversitas M uhammadiyah Yogyakarta, Telp. 082214268377 \\ arsyl@umy.ac.id
}

\begin{abstract}
ABST RAK
Penelitian ini adalah suatu kajian sintaksis dan semantis mengenai setsuzokujoshi noni dan temo dalam percakapan serial drama Jepang. Noni dan temo sering digunakan oleh orang Jepang dalam kehidupan sehari-hari, salah satunya sering ditemukan juga penggunaannya dalam acara televisi, serial drama Jepang, dan lain-lain. Noni dan temo merupakan salah satu materi pembelajaran pada jenjang S1. Dalam tesis ini penulis mencoba untuk mendeskripsikan apakah materi noni dan temo yang diberikan di bangku perkuliahan sama dengan penggunaannya dalam realita kehidupan sehari-hari masyarakat Jepang. Menurut para ahli makna noni dan temo dikategorikan menjadi masing-masing empat makna sesuai konteks kalimatnya, noni yang bermakna konsekwensi yang gagal, hubungan yang kontras, diluar prediksi, serta menyatakan perasaan kecewa. Sementara temo bermakna untuk menyatakan hal yang kontradiksi, kalimat majemuk, pertanyaan terhadap suatu hal, serta bermakna kenyataan dan kebalikan dari kenyataan. Selain kategorisasi tersebut, akan dilihat fungsi noni dan temo yang digunakan bersama pada kalimat bermakna keadaan, aktifitas, pengaruh, maksud atau keinginan, serta kalimat tanya.Hasil penelitian ini menunjukkan bahwa makna dan fungsi noni dan temo yang dikemukakan oleh para ahli, semuanya muncul pada serial drama Jepang. Sementara pada teks bahan ajar ada yang tidak muncul. Yaitu, noni yang bermakna mengontraskan suatu hal tidak ditemukan. Kemudian, pada teks bahan ajar, temo yang digunakan bersama kalimat bermakna pengaruh, kalimat yang bermakna maksud atau keinginan tidak ditemukan. Selanjutnya, noni yang digunakan bersama kalimat yang bermakna aktifitas, kalimat yang bermakna pengaruh, kalimat yang bermakna maksud atau keinginan, serta kalimat tanya tidak ditemukan.
\end{abstract}

Kata kunci: noni, temo, serial drama Jepang, sintaksis, semantis

\section{ABSTRACT}

This research is a syntax and semantic study about setsuzokujoshi noni and temo within dialogues of Japanese drama series. The Japanese using noni and temo in their daily life. For instance we could find the usage of noni and temo in television programs, Japanese drama series, etc. Noni and temo are part of learning materials that have been given in the lecture during the process to get first university degree. In this thesis the author tries to describes whether the learning materials regarding to the themes noni and temo that have been given during the lecture match with the usage of noni and temo in Japanese real daily life.According to the experts the meaning of noni and temo are classified into four categories of meaning depend on its context, noni which means fail consequence, a contrast relation, unpredictable, and expression of dissapointment. The meaning of temo are expression of contradiction, a compound sentence, question about something, real- 
ity and the opposite of the reality. Other than those categories, the functions of noni and temo will be seen in its usage toether in a sentence that explain about situations, activity, influence, intention or desire, and interogative sentence. The results of this research indicated that all of the meaning and function of noni and temo state by the experts, appear in Japanese drama series. Meanwhile, there are several meaning and functions that not appeared in learning material textes. They are noni that explain contrast relation, and temo that used with a sentence meaning influence, intention and desire. Also noni that used with a sentence meaning activity, influence, intention and desire, and noni in interogative sentence.

Keywords: noni, temo, Japanese drama series, syntax, semantic.

\section{PENDAHULUAN}

Selama ini penelitian linguistik yang sering dilakukan meliputi kajian fonologi, morfologi, sintaksis, semantis, dan pragmatis. Dalam linguistik bahasa Jepang juga dapat dikaji mengenai beberapa hal seperti kalimat, kosakata, atau bunyi ujaran, bahkan sampai pada bagaimana bahasa diperoleh, serta bagaimana sosiokultural yang memengaruhi masyarakat pengguna bahasa tersebut. Linguistik bahasa Jepang melahirkan berbagai cabang linguistik, diantaranya adalah sebagai berikut (Sutedi, 2011: 6).

- Fonetik (0 nseigaku) yaitu: ilmu yang mengkaji segala sesuatu berkenaan dengan bunyi, termasuk proses bagaimana bunyi dapat diciptakan dan diterima oleh pendengarnya.

- Fonologi (0 n-nron) yaitu: ilmu yang mengkaji tentang fonemfonem dan aksen suatu bahasa.

- Morfologi (K eitairon) yaitu: ilmu yang mengkaji bagaimana kata-kata dapat terbentuk.

- Sintaksis (Tougoron) yaitu: ilmu yang mengkaji tentang struktur pembentukan dari sebuah kalimat.

- Semantik (Imiron) yaitu: ilmu yang mengkaji tentang makna kata, frase, dan klausa dalam suatu kalimat.

- Pragmatik (G oyouron) yaitu: ilmu yang mengkaji tentang makna serta penggunaan nya dalam kehidupan yang sebenarnya.

- Sosio-linguistik (Shakai gengogaku) yaitu: salah satu cabang linguistik yang mengkaji mengenai bahasa dan pengguna bahasa itu sendiri.

Berbicara mengenai kajian sintaksis dan semantis erat kaitannya dengan kajian mengenai kalimat, klausa, maupun kata. 
Di dalam kelas kata, ada partikel penghubung (setsuzokujoshi) menjadi salah satu bagian penting yang digunakan dalam kalimat untuk men ghubungkan kata-kata sebelumnya terhadap kata-kata yang ada pada bagian berikutnya Sudjianto (2007: 182). Dari setsuzokujoshi tersebut ada noni dan temo, yang berfungsi untuk menghubungkan kalimat bermakna kontradiksi.

(1) 無料でも、わたしは行きません。

Muryou demo, watashi wa ikimasen.

'Walaupun gratis, saya tidak akan pergi.'

(Tomita, 1991:125)

(2) 無料なのに、Bさんは行きません。

Muryou nanoni, $B$ san wa ikimasen.

'Walaupun gratis, B san tidak akan pergi.'

(Tomita, 1991:125)

Kedua setsuzokujoshi di atas menjelaskan hubungan kontradiksi antara gratis dan pergi ke suatu tujuan yang tidak disebutkan, dalam bahasa Indonesiakeduanya diartikan menjadi 'meskipun, walaupun, atau padahal', Matsuura (1994: 734, 1066). Secara umum terjemahan tersebut berterima namun, jika dikaji lebih mendalam maka akan muncul deskripsi yang lebih rinci mengenai bagaimana noni maupun temo digunakan dalam bahasa Jepang.

\section{METODE}

M etode pen elitian yang digunakan dalam penelitian ini adalah metode deskriptif dengan pendekatan kualitatif. M etode deskriptif merupakan metode penelitian yang dilakukan untuk menggambarkan, menjabarkan suatu fenomena yang terjadi saat ini dengan menggunakan prosedur ilmiah untuk menjawab masalah secara aktual Sugiyono (2011). Penelitian ini juga menggunakan metode kepustakaan (library research), yaitu studi kepustakaan atau pengumpulan data-data dan informasi yang bersumber dari serial drama, buku-buku, kepustakaan yang ada kaitannya dengan kedua setsuzokuoshi tersebut. 


\section{INST RU MEN DAN DATA PENELITIAN}

Sesuai dengan sifat dari penelitian kualitatif pada umumnya, peneliti bertindak sebagai instrumen penelitian, dengan menggunakan kartu data dan melakukan studi literatur. Sumber data pertama diambil dari beberapa judul drama Jepang untuk menggambarkan bagaimana pemakaian data yang hendak diteliti digunakan dalam kehidupan sehari-hari. D rama yang hendak dijadikan data penelitian berjumlah tiga buah judul yang dirilis dari tahun 2009 hingga 2012, adapun judul-judulnya adalah sebagai berikut:

a. Buzzer Beat (BB, 2009)

b. Taisetsuna Koto Wa Subete Kimi Ga O shiete Kureta (TK, 2011)

c. G reat Teacher O nizuka (GT, 2012)

Kemudian sumber data kedua diambil dari buku teks bahan ajar yang dijadikan pedoman pembelajaran di JPBJ FPBS U PI tahun ajaran 2013/ 2014, yaitu semua buku D okkai dan Bunpou. Adapun judul-judulnya teks bahan ajar yang digunakan adalah sebagai berikut:

a. Shokyuu dokkai 2 (SD 2)

b. Joukyuu dokkai 1 (JD 1)

c. Joukyuu dokkai 2 (JD 2)

d. A kademiku japaniizu kenkyuukai (AJ)

e. N ew A pproach chuukyuu nihon go (NA)

\section{METODE ANALISIS DATA}

M etode analisis data yang akan dilakukan dalam penelitian ini dilakukan dalam tiga tahapan. Pertama, Data penelitian merupakan jitsurei, yaitu data yang diambil dari teks konkret yang terdapat dari serial drama Jepang dan teks bahan ajar. Kemudian pada tahap kedua data-data yang sudah ditran skripsikan tersebut dianalisis berdasarkan teori fungsi, dan teori makna yang dikemukakan para ahli dengan cara analisisnya berupa analisis deskriptif. Pada tahap ketiga data dari serial drama dan teks bahan ajar dikomparasikan dan dijabarkan dalam beberapa teknik 
analisis, hingga pada tahap pengambilan kesimpulan atau generalisasi.

\section{HASIL DAN PEMBAHASAN}

\section{PERSAMAAN MAKNA SET SU ZOKUJOSHI NONI DAN}

\section{TEMO}

1.1. Menyatakan hubungan yang bertolak belakang antara yang ada di S1 dan S2.

(3) 雨が降っているのに、出かけていった。

A me ga futteiru noni, dekaketa.

'Padahal turun hujan, tapi tetap pergi.'

(Sagawa, 1998:472)

(4) 明日は降っても、行くつもりだ。

A shita wa futtemo, ikutsumori da.

'M eskipun besok turun hujan, saya berencana pergi.'

(O gawa, 1982:213)

Kedua setsuzokushi tersebut biasanya digunakan untuk menghubungkan antara S1 dan S2, dimana S1 berupa syarat yang harus dipenuhi sehingga muncul S2 yang merupakan kondisi yang terjadi karena diawali syarat sebelumnya. C ontoh di atas menunjukkan persamaan pola antara syarat dan hasil yang terjadi merupakan hal yang berlawanan, tidak seperti pemikiran logis pada umumnya.

\section{PERBEDAAN MAKNA SET SU ZOKU JOSHI NONI DAN TEMO}

2.1. Noni

〜過去形＋のに〜

あと5秒早ければ始発電車に間に合ったのに。

A to 5 byou hayakereba shihatsu densha ni maniatta noni.

'Padahal kalau saja saya lebih cepat 5 detik, pasti saya dapat kereta keberangkatan awal.'

(Sagawa, 1998:474)

Pada bagian terdapat perbedaan makna diantara keduanya meskipun sama-sama digun akan dalam kalimat syarat yang berla- 
wanan noni memiliki makna adanya kekecewaan yang diungkapkan oleh pembicara, lain halnya kalimat yang dimarkahi den gan temo hasil berlawanan yan g diungkapkan pada S2 meskipun berlawanan namun pembicara merasa biasa saja terhadap hal tersebut. 2.1.1. Noni dapat menyatakan suatu hal yang diluar dugaan

（6）5月なのに、何でこんなに暑いんだあろう。

5 gatsu nanoni, nande konna ni atsui ndarou.

'Padahal bulan mei, tapi kenapa sepanas ini.'

(Sagawa, 1998:473)

N oni dapat bermakna sesuatu yang diluar dugaan, apa yang ada di S2 bertolak belakang dengan pernyataan yang terdapat di S1, namun sesuatu diluar dugaan di sini merupakan hal yang dampaknya dirasakan langsung oleh pembicara.

2.1.2. Noni dapat menyatakan suatu hal yang kontras

(7) 昨日はいい天気だったのに今日は雨だ。

Kinou wa ii tenki datta noni, kyou wa ame da.

'M eskipun kemarin cuacanya cerah, tapi hari ini hujan.'

(Sagawa, 1998:473)

$N$ oni dapat bermakna sesuatu yang kontras, apa yang ada di S1 dan S2, menunjukkan sebuah hubungan perbandingan yang kontras, pada (17) dapat dilihat hubungan tersebut yaitu perbandingan antar cuaca yang cerah dihari kemarin sementara saat ini hujan turun.

2.1.3. Noni bermakna lebih objektif dibandingkan Temo

（8）彼女は病気なのに、会社一行きました。

Kanojyo wa byouki nanoni, kaisha eikimashita.

'M eskipun dia sakit tapi tetap pergi ke kantor.'

(Tomita, 1991:119)

Noni dapat menunjukkan makna yang lebih objektif dibandingkan temo. Pada (18) konteks 'datang ke kantor meskipun sedang sakit', bukan pengandaian predikat dalam bentuk kala lampau men unjukkan bahwa kejadian tersebut sudah terjadi. Sehingga, noni dapat digunakan manakala sesuatu hal sudah terbukti terjadi. 


\subsection{TEMO}

2.2.1. Temo dapat digunakan dalam kala masa depan

(9) 高くても買おうと思ういます。

Takakutemo, kaou to omoimasu.

'M eskipun harganya mahal, saya bermaksud untuk beli.'

(O gawa, 1982:213)

Pada bagian ini akan dijelaskan makna yang terdapat pada temo, pada (19) temo berada pada kalimat yang berpola 'bermaksud untuk melakukan sesuatu', sehingga dapat pada konteks tersebut, dapat ditarik kesimpulan bahwa temo dapat digunakan untuk mengungkapkan sesuatu hal yang akan dilakukan dimasa yang akan datang.

\subsubsection{Temo dapat digunakan dalam kalimat majemuk setara}

$$
\begin{gathered}
\text { うちの子供は、ニンジンでも、ピーマンでも、 } \\
\text { 好き嫌いを言わないで食べます。 }
\end{gathered}
$$

$U$ chi no kodomo wa, ninjin demo, piiman demo, suki kirai o iwanaide tabemasu.

'Anak di rumah apakah wortel maupun paprika, makan saja tanpa bilang suka atau tidak.'

(Sagawa, 1998:273)

Perbedaan temo dibandingkan dengan noni, yaitu temo dapat digunakan dalam kalimat majemuk setara. Ketika S1 dan S2 merupakan perbandingan suatu hal yang dianggap memiliki kategori atau tingkat yang setara maka temo dapat digunakan.

\subsubsection{Temo bermakna lebih subjektif dibandingkan Noni}

(11) 私先生が行っても、行きません。 (Tomita, 1991:121)

Watashi sensei ga ittemo, ikimasen.

'M eskipun sensei pergi, saya tetap tidak akan pergi.'

Berbeda dengan noni, temo bersifat lebih subjektif. Pada (22) kehendak pembicara 'tidak akan pergi' belum bisa divalidasi karena syarat di awal kalimat 'meskipun sensei pergi' belum terjadi. Dari konteks kalimat ini karena baik syarat di S1 maupun hasil 
dari syarat di $\mathrm{S} 2$ belum terjadi, boleh jadi ada kemungkinan suatu saat hasil S2 berubah. Sehingga, kalimat yang menggunakan temo bertendensi lebih subjektif dibandingkan dengan kalimat yang menggunakan noni.

\subsubsection{Temo dapat digunakan dalam suatu hal yang bermakna} percuma jika dilakukan

(12) 宿題は多寸ぎて、やってもやっても終わらない。 Shukudai wa oosugite, yattemo - yattemo owaranai.

'Tugas ini terlalu banyak, dikerjakan pun tidak selesai-selesai.' (Sagawa, 1998:273)

Perbedaan antara noni dan temo yang terakhir adalah temo, dapat digunakan dalam kalimat yang menyatakan hal yang percuma jika dilakukan.

Berikut ini merupakan klasifikasi makna setsuzokujoshi temo yang terdapat pada data berdasarkan teori para ahli.

\section{MAKNA SET SU ZOKU JO SHI TEMO}

3.1. Menyatakan hal yang kontradiksi

大丈夫だよ 焦って結婚しなくても私は直輝の

そばにいるから。

Daijyoubu dayo asette kekkon shinakutemo watashi wa naoki no soba ni iru kara

Tidak apa-apa tidak usah terburu-buru menikah pun, aku akan berada di samping Naoki.

(Buzzer Beat, episode 1)

Makna temo dalam kalimat ini mengkontradiksikan S1 yang berisi pernyataan negasi yaitu "tidak menikah" sementara, pada S2 pembicara menyatakan kebalikan dari pernyataan sebelumnya, tidak masalah dengan status hubungan yan gsekarang meski tidak menikah pun, akan berada menyertai seperti halnya jika menikah. 
3.2. Menyatakan kalimat majemuk

(14)

はははあ上等だ。教育評論家でも弁護士

でも連れてこい。

$\mathrm{H}$ ahaha, jyoutou da kyouiku hyouronka demo bengoshi demo tsurete koi.

Lakukan saja, pengacara atau jurnalis datanglah kemari.

( $G$ reat Teacher 0 nizuka, episode 1 )

Dalam kalimat ini temo sebagai penghubung konstruksi kalimat majemuk, S1 dan S2 berisi hal yan gsifatnya setara. Antara "jurnalispendidikan" dan "pen gacara" keduanya dianggap berada pada tingkatan yang hampir sama, kemudian sebagai kalimat predikatif, predikat menunjukkan hasil yang sama "yang manapun" subjek tidak akan sedikitpun menciutkan nyalinya.

\subsection{Menyatakan pertanyaan terhadap suatu hal}

(15) 君とはいくら話をしても無䭾なようだ。

K imi to wa ikura hanashi o shitemo muda na youda.

Bicara denganmu hanya membuang-buang waktu saja.

( $G$ reat Teacher 0 nizuka, episode 2 )

Temo dalam kalimat (3) didahului dengan kemunculan kata introgatif, menunjukkan makna penegasan, apa yang dinyatakan di S1 tidak akan mempengaruhi apa yang akan terjadi di S2. Di sini dinyatakan bahwa seberapa kalipun berbicara hasilnya sama saja, percuma.

3.4. Kenyataan dan kebalikan dari kenyataan

$$
\begin{aligned}
& \text { たとえ娘がおおかみ少女でもあんたが信じね } \\
& \text { えでどうすんだよ。 }
\end{aligned}
$$

Tatoe musumega ookami shoujou demo anta ga shinji neededousun dayo.

Bahkan meski dia menangis meraung-raung seperti serigala jika kau tidak mempercayainya, siapa lagi yang akan melakukannya? 
(G reat Teacher 0 nizuka, episode 2 )

Temo dalam kalimat ini didahului dengan kemunculan tatoe sebagai ciri kalimat yang bermakna bertentangan dengan realita. Realita terdapat pada S2 tepat setelah kata yang dimarkahi oleh temo, "tidak mempercayainya" kenyataannya hal itu yang terjadi sebenarnya. Kemudian S1 menjadi hal yang bertentangan dengan realita.

\section{MAKN A SET SUZOKUJOSHI NONI}

4.1. Konsekwensi yang gagal

（17）強いのに、才能あるくせに何怯えてんのよ。

Tsuyoi noni, sainou aru kuseni nani obieten no yo.

Padahal kau kuat, bertalenta juga, apa yang kau takutkan?

(Buzzer B eat, episode 2)

Dalam kalimat ini noni menjadi penghubung antara S1 dan S2, makna yang pertama menunjukkan sebuah alasan yang berlawanan dengan akibatnya. A kibat padaS2 dinyatakan dengan "ada yang ditakutkan", padahal di S1 dinyatakan bahwa subjek memiliki karakteristik "kuat".

\subsection{Hubungan yang kontras}

$$
\text { なんだよ、去年は450だったのに315 }
$$

ってこんな年俸で食ていけないよ。

$\mathrm{N}$ andayo, kyonen wa 450 datta noni 315 ttekonna nenpou de kutte ikenaiyo.

A pa-apaan? Tahun Ialu saja aku digaji 450 kalau 315 seperti ini aku tidak bisa makan.

(Buzzer B eat, episode 1)

Dalam kalimat ini noni menjadi penghubung antara S1 dan S2. Untuk makna yang kedua noni mengontraskan suatu hal dalam jangka waktu tertentu. $\mathrm{H}$ al yang dikontraskan adalah besaran gaji yang diterima pembicara san gat berbeda dengan apa yang diterimanya ditahun sebelumnya 


\subsection{Diluar Prediksi}

(19)もう別れたのに、直輝の話ばかり。

M ou wakareta noni naoki no hanashi bakari.

Walaupun sudah putus, tapi aku masih saja membicarakan Naoki.

(Buzzer Beat, episode 8)

Dalam kalimat ini noni menjadi penghubung antara S1 dan S2, hal yang terjadi adalah kejadian yan gdiluar dugaan pembicara dimana pembicara tetap membicarakan seseorang padahal mereka berdua sudah tidak menjalani hubungan percintaan lagi. Kemudian, dampaknya dirasakan langsung oleh dirinya sen diri, tidak ada hubungannya dengan pihak lain.

\subsection{Menyatakan perasaan kecewa}

(20)

$$
\text { すごいですね、鬼塚先生私は何もできなかっ }
$$

たのに。

Sugoidesune 0 nizuka sensei, watashi wa nani mo dekinakatta noni. G uru O nizuka sangat luar biasa, aku tak bisa apa-apa.

(G reat Teacher 0 nizuka, episode 2)

Dalam kalimat ini noni tidak diletakkan di tengah-tengah kalimat, melainkan di akhir kalimat, dengan kondisi seperti ini maka pernyataan dari kalimat tersebut akan bernuansa adanya rasa kecewa. Pembicara merasa bahwa kapasitas dirinya tidak sebaik orang lain sehingga, timbul perasaan kecewa terhadap diri sendiri.

\section{FU NGSI TEMO}

5.1. Digunakan bersama kal imat yang ber makna keadaan (joutaibun)

(21) 仕事の代わりはいても親の代わりはいねえんだよ。 Shigoto no kawari wa itemo oya no kawari wa ineen dayo.

Di kantor anda bisa digantikan, tapi di rumah anda tak tergantikan.

( $G$ reat Teacher 0 nizuka, episode 2 ) 
Pada kalimat ini S1 diisi dengan kalimat yang menyatakan keadaan ditandai dengan adanya iru kemudian padaS2, predikat diisi dengan verba yang menyatakan keadaan (joutai) kemudian pada "ineen", "tidak ada" di sini menyatakan "keadaan lingkungan rumah yang tidak ada siapapun". Maka di sini S1 diisi dengan keadaan dan S2 diisi pula dengan keadaan. Diakhiri dengan penanda kala non lampau.

5.2. Digunakan bersama kalimat yang bermakna aktifitas (ugoki no bun)

\section{毎日、自分の学校へいくのはもちろん、}

(22) 授業が終わっても、すぐには家には帰らないで、 塾や予備校へ行って、夜まで勉強する。

M ainichi, jibun no gakkou eiku no wa mochiron, jugyou ga owattemo, sugu niwa ie ni wa kaeranaide, jyuku ya yobikou e itte, yoru made benkyou suru.

Setiap hari, tentu saja pergi ke sekolah, setelah selesai belajar, segera tidak pulang dulu ke rumah, pergi ke tempat les ke bimbel, hinga malam belajar.

(Jyoukyuu Dokkai 1, halaman 15)

Pada kalimat ini S1 diisi oleh kalimat yang menyatakan keadaan yaitu saat pelajaran selesai. Kemudian, S2 diisi oleh kalimat yang menyatakan aktifitas yaitu, serangkaian kegiatan yang dilakukan pembicara sampai malam hari. M aka, di sini S1 diisi oleh kalimat yang menyatakan keadaan, sementara S2 diisi oleh kalimat yang menyatakan aktifitas. Dengan penanda kala non lampau.

5.3. Digunakan bersama kal imat yang bermakna mempengaruhi (hataraki-kake no bun)

(23) 過去の栄光でも思い出してがんばって。

K ako no eiko demo omoidashite ganbatte.

Walaupun dulu kau hebat, jika kau ingat itu berusahalah untuk lebih baik.

(Buzzer Beat, episode 2) 
Pada kalimat ini S1 diisi dengan kalimat yang menyatakan keadaan, kemudian pada S2, predikat verbal berkonjugasi dengan pola te kudasai, yang dalam sebuah kalimat berfungsi untuk menyampaikan keinginan pembicarakepada lawan, agar melakukan sesuatu, di sini pembicara menyatakan sebuah permohonan (irai) kepada lawan bicara, untuk berusaha ban gkit lagi seperti halnya yang lawan bicara alami di masa lalu. Maka di sini S1 diisi dengan kalimat yang menyatakan keadaan sementara S2 diisi dengan kalimat yang menyatakan mempen garuhi. Kemudian, penanda kala dalam kalimat ini adalah non lampau.

\subsection{Digunakan bersama kal imat yang bermakna menyatakan} maksud atau keinginan (ishi/ ganbou no hyoushutsu bun)

(24)離れてても莉子がいると思うと、強くなれる。

$\mathrm{H}$ anaretetemo Riko ga iru to omou to, tsuyoku nareru.

Meskipun kita berpisah, mengingat aku memilikimu, aku akan menjadi kuat.

(Buzzer Beat, episode 10)

Pada kalimat ini S1 diisi oleh kalimat yang menyatakan aktifitas kemudian S2 diisi oleh kalimat yang berfungsi untuk menyampaikan keinginan atau maksud pembicara kepada lawan, di sini ditandai dengan adanya verba nareru, namun keinginan tersebut dilakukan hanya ditujukan untuk dirinya sendiri., bahwa pembicara akan menjadi kuat dengan mengingat ada seseorang yang selalu menunggunya, dengan kata lain seseorang tersebut merupakan sumber harapannya. Maka di sini S1 diisi oleh kalimat yang menyatakan aktifitas sementara S2 diisi oleh keinginan atau maksud. Kemudian, penan da kala dalam kalimat ini adalah non lampau.

5.5. Digunakan bersama kal imat yang ber makna berita (nobetate no bun)

えどじだいにすもうはプロスポーツになりました。 (25) みんなゆっくりすもうを見ました。ご飯を食べたり、 お茶を飲んだりしてもよかった。 
E do jidai ni sumo wa puro supootsu ni narimashita. M inna yukkuri sumou o mimashita. Gohan o tabetari, ocha o nondari shitemo yokatta.

Di zaman Edo sumo menjadi olahraga profesional. Semua orang dengan santai men onton sumo, sambil makan, minum teh pun nikmat.

(Shokyuu Dokkai 2 Semester 2, halaman 8)

Pada kalimat ini S1 diisi oleh kalimat yang menyatakan sebuah informasi baru mengenai bagaimana situasi orang-orang menikmati olahraga sumo di masa Edo. Maka di sini diisi oleh kalimat yang menyatakan berita dengan penanda kala lampau.

\subsection{Digunakan bersama kalimat yang menyatakan pertanyaan} (toikake no bun)

(26) 悩みなんかあっても誰がてめえなんかに話すかよ。 N ayami nanka attemo dare ga temee nanka ni hanasu kayo. jika memang ada masalah kenapa aku harus bilang padamu? (G reat Teacher 0 nizuka, episode 3)

Pada bagian ini S1 diisi oleh kalimat yan g menyatakan keadaan ditandai dengan adanya verba aru yang berkonjugasi kedalam bentuk temo. Sementara, S2 diisi oleh kalimat yang berfungsi untuk menyampaikan pertanyaan, keraguan atau ungkapan emosi hal tersebut ditandai dengan partikel ka yang digunakan dalam kalimat interogatif. M aka di sini S1 diisi dengan kalimat yang menyatakan keadaan sementara S2 diisi dengan kalimat yang menyatakan pertanyaan. Kemudian, penanda kala pada kalimat ini adalah non lampau.

\section{FUNGSI NONI}

6.1. Digunakan bersama kalimat yang ber makna keadaan (joutaibun)

(27)生徒がこんな目に遭ってるのに何にもできないなんて。

Seito ga konna me ni atteru noni nani mo dekinai nante.

Kau bahkan tidak bisa melindungi murid dari bahaya.

( $G$ reat Teacher 0 nizuka, episode 5 ) 
Pada kalimat ini S1 diisi oleh kalimat yang menyatakan aktifitas yaitu 'melindungi'. Sedangkan S2 diisi oleh kalimat yang menyatakan keadaan (joutai) dapat dilihat dari adanya verba dekiru dalam bentuk negatif. Keadaan yang digambarkan adalah kondisi dimana seorang guru yang tidak bisa melakukan apa-apa saat murid-muridnya dalam keadaan bahaya. Maka di sini S1 diisi oleh kalimat yang menyatakan aktifitas, sementara S2 diisi oleh kalimat yang menyatakan keadaan. Kemudian penandakala pada kalimat ini adalah non lampau.

6.2. Digunakan bersama kal imat yang bermakna aktifitas (ugoki no bun)

お母さんに言えないよ、最近はバイトとダイエット

しかしてないのに。

0 kaasan ni ienai yo, saikin wa baito to daietto shika shitenai noni Aku tak bisa memberitahu ibuku, soal pekerjaan sampingan dan pola makan ku selama ini.

(Buzzer Beat, episode 2)

U ntuk fungsi yang kedua ini pada kalimat (57) noni diletakkan di akhir kalimat memarkahi predikat berupa verba yang menyatakan perbuatan (ugoki no bun), yaitu menjelaskan perbuatan yang sedang dilakukan pada kalimat ini adalah "pekerjaan sampingan dan diet". Maka, di sini hanya terdapat S1 saja yang menyatakan aktifitas. Kemudian, penanda kala dalam kalimat ini adalah non lampau.

6.3. Digunakan bersama kal imat yang ber makna mempengaruhi (hataraki-kake no bun)

(29)みんなと一緒に頑張ってるのにそんなこと言わないで。

$M$ inna to isshoni ganbatteru noni sonna koto iwanaide

Semua sudah bekerja keras jangan bilang begitu.

( $G$ reat Teacher 0 nizuka, episode 4)

Pada kalimat ini S1 diisi oleh kalimat yang menyatakan keadaan upaya kerja keras yang dilakukan semua orang. Kemudian 
pada S2 noni digunakan bersama kalimat yang menyatakan maksud dari pembicara yang menghen daki lawan bicara melakukan sesuatu meirei (perintah), yang dikehen daki oleh pembicara yaitu menyuruh lawan bicara untuk tidak berkata yang tidak pantas. Maka di sini S1 diisi oleh kalimat yang menyatakan keadaan sementara, S2 diisi oleh kalimat yang menyatakan pengaruh. Kemudian, penanda kala dalam kalimat ini adalah non lampau.

6.4. Digunakan bersama kalimat yang bermakna menyatakan maksud atau keinginan (ishi/ ganbou no hyoushutsu bun)

$$
\begin{aligned}
& \text { でも、みんな行くのリーダー私が行かないわけに } \\
& \text { 行かなくて、本当は行きたくなかっただけなのに。 }
\end{aligned}
$$

Demo, minna iku no riidaa watashi ga ikanai wakeni ikanakute, hontou wa ikitakunakatta dake nanoni.

Tapi semuanya pergi, karena pemimpin aku harus pergi, sebenarnya aku tidak ingin pergi kesana.

(Buzzer B eat, episode 3)

Pada kalimat (63) noni berada di akhir kalimat digunakan dengan kalimat yang menyatakan maksud, harapan, atau keinginan. Hal yang dikehen daki oleh pembicara adalah mengharapkan jika dirinya tidak pergi namun, karena dirinya adalah seorang pemimpin, maka dia harus pergi. M aka di sini noni digunakan bersama kalimat yang menyatakan maksud dan harapan den gan penanda kala dalam kalimat ini adalah lampau.

6.5. Digunakan ber sama kalimat yang ber makna berita (nobetate no bun)

(31) せっかく海に行ったのに、波が高くて泳げなかった。

Sekkaku umi ni itta noni, nami ga takakute oyogenakatta.

Padahal sudah pergi ke laut, tapi ombaknya tinggi jadi tidak dapat berenang. (NA, halaman 77)

Untuk kalimat ini S1 diisi oleh kalimat yang menyatakan 
aktifitas mengenai pembicara yan g telah pergi ke laut. Kemudian pada S2, diisi oleh kalimat yang menyatakan informasi baru sebuah berita, bahwa rencana berenang di laut gagal karena ombaknya besar. Maka di sini, S1 diisi oleh kalimat yang menyatakan aktifitas. Sementra S2 diisi oleh kalimat yang menyatakan berita, dengan penanda kala lampau.

6.6. Digunakan bersama kal imat yang menyatakan pertanyaan (toikake no bun)

(32) 同じスポーツ選手なのにこの違いなんですか。

0 naji supootsu henshu nanoni kono chigai nandesuka?

Padahal kita sama-sama atlit olahraga, kenapa perbedaannya jauh sekali?

(Buzzer B eat, episode 1)

Pada kalimat ini S1 diisi oleh kalimat yang menyatakan keadaan, nomina sebelum noni, menunjukkan sebuah keadaan mengenai dua orang dengan profesi yang sama. Kemudian, S2 diisi oleh kalimat yang menyatakan sebuah pertanyaan, pembicara mempertanyakan kapasitas yang dimilikinya dibandingkan dengan orang lain yang jaraknya begitu jauh, hingga menimbulkan rasa penasaran terhadap faktor yang memengaruhi hal tersebut. M aka di sini, S1 diisi dengan kalimat yang menyatakan keadaan, sementara S2 diisi dengan kalimat yang menyatakan sebuah pertanyaan. kemudian penanda kala dalam kalimat ini adalah non lampau.

\section{SIMPULAN}

1. Persamaan makna setsuzokujoshi noni dan temo.

a. Keduanya memiliki hubungan yang bertolak belakang antara S1 dan S2.

2. Perbedaan makna setsuzokujoshi noni dan temo.

a. N oni dapat menyatakan suatu hal yang diluar dugaan, di mana dampaknya dirasakan langsung oleh pembicara. 
b. N oni dapat menyatakan suatu hal yangkontras, digunakan saat konteksnya membandingkan dua kondisi yang jauh berbeda.

c. N oni bermakna lebih objektif dibandingkan Temo, karena digunakan dalam kalimat yang konteksnya sudah terbukti terjadi.

d. N oni yang terletak di akhir kalimat bermakna adanya perasaan kecewa pada0diri pembicara terhadap suatu hal.

e. Temo dapat digunakan dalam kala masa depan, yaitu dapat digunakan untuk konteks kalimat yang bersifat prediksi akan terjadi.

f. Temo dapat digunakan dalam kalimat majemuk setara, ketika dalam suatu kalimat terdapat dua hal yan g dianggap sepadan.

g. Temo bermakna lebih subjektif dibandingkan noni, berbeda dengan noni karena dapat digunakan dalam kalimat yang peristiwanya belum terjadi.

h. Temo dapat digunakan dalam suatu hal yang bermakna percuma jika dilakukan, apapun yang dinyatakan di awal kalimat hasilnya sama saja.

Melalui pemaparan di bagian sebelumnya, dapat diketahui bahwa teori mengenai makna setsuzokujoshi noni dan temo yang dikemukakan para ahli sesuai dengan temuan pada data, meski demikian ada beberapa kategori yang tidak ditemui pada buku teks bahan ajar, noni yang bermakna men gontraskan (taihi) suatu hal, tidak ditemukan.

Selanjutnya, sama halnya dengan fungsi kedua setsuzokujoshi tersebut, mengenai pengunaan dengan kalimat bermakna lain, hasil menunjukkan pada teks bahan ajar, temo yang digunakan bersama kalimat bermakna pengaruh hataraki-kakeno bun, kalimat yang bermakna maksud atau keinginan (ishi/ ganbou no hyoutsutsu bun) tidak ditemukan. Kemudian noni yang digunakan bersama kalimat yang bermakna aktifitas (ugoki no bun), kalimat yang bermakna pengaruh (hataraki kakeno bun), kalimat yang bermakna maksud atau keinginan (ishi/ ganbou no hyoutsutsu bun), serta 
kalimat tanya (toikake no bun) tidak ditemukan. Sementara di sisi lain dapat ditemui pada dialog yang terdapat pada serial drama. Ini mengandung arti bahwa, teori yang dikemukakan para ahli semuanya digunakan dalam kehidupan sehari-hari yang direpresentasikan melalui serial drama, temuan ini dapat menjadi tambahan wawasan baik bagi pengajar, khususnya bagi pembelajar. Pada konteks yang sebenarnya noni dan temo tidak hanya berarti meskipun, walaupun, atau padahal dalam bahasa Indonesia, tetapi memiliki makna dan penggunaan yang beragam dengan konteks tertentu.

\section{DAFTAR PUSTAKA}

Matsuura, Kenji. (1994). Kamus Bahasa Jepang-Indonesia, Kyoto Sangyo University Press. Japan

Ogawa, Yoshio. (1982). Nihon Go Kyouiku Jiten. Tokyo: DaiosamuToshokan Oyanagi, Noboru. (2004). New Approach Japanese Intermediate Course. Tokyo: SD Sudjianto, Dahidi.(2008). Pengantar Linguistik Bahasa Jepang. Jakarta: Kesaint Blanc Sugiyono.(2011).Metode Penelitian Pendidikan.Bandung: Alfabeta Sutedi, Dedi.(2011). Dasar-Dasar Linguistik Bahasa Jepang. Bandung: Humaniora Tomita, Takayuki. (1990). Bunpou Kiso Chisiki to Sono Oshiekata. Tokyo:

Bonjinsha 